\title{
POŠTA
}

TELEKOMUNIKACIE A

ELEKTRONICKY OBCHOD

\section{HLADANIE MEDZNEJ MIERY AKCEPTÁCIE INTERNETOVEJ REKLAMY V PODMIENKACH VYBRANÉHO ZÁKAZNÍCKEHO SEGMENTU - I.}

\author{
Vladimíra Žiačková*, Radovan Madleňák*
}

\section{Úvod}

Produkt alebo služba nikdy nie je prijímaná bez výhrad, to je právo každého zákazníka v trhovom prostredí. Podobné právo vzniká aj pre recipienta online reklamy - prijímat' reklamu s možnost'ou výhrad, ale zároveň sám reklamu tvorit' (napr. prostredníctvom odporúčaní).

Dnešná internetová reklama, to nie sú len reklamné bannery, emailová reklama alebo platené odkazy na stránkach. Medzi nové trendy komunikácie patrí reklama na komunitných a sociálnych weboch ako je napr. Facebook, MySpace alebo Twitter. Vd'aka rýchlejšiemu internetu sa stále viac využíva i videoreklama napr. na serveri YouTube. [1]

Priamym predpokladom novej online reklamy, ktorá vzniká v rámci komunít, networkingových stránok, blogov a participačnej architektúry je aktivita na strane používatel'ov. Návštevníci, hlavne pokial' ide o mladých l’udí, radi ovplyvňujú dianie na webe svojimi názormi a reakciami. Často využívajú diskusné fóra, chaty, hlasovania, ankety a hry. Tento segment sa však často „zanedbáva“ a je vel'mi zložité odhadnút' dôvod takéhoto prístupu. Pravdepodobne je to spôsobené tým, že inzerenti tento segment považujú za neperspektívny, ked’že ide o mladých neproduktívnych l'udí, zvyčajne študentov, ktorý na základe internetovej reklamy nakupujú produkty v menšej miere.

Rovnako inzerenti majú na internete možnost' zacielit' reklamu presne tam, kde najviac chodia potenciálni zákazníci a použit' slová, ktoré najčastejšie vyhl'adávajú vo vyhl'adávačoch. Reklama môže byt' zobrazovaná v presne vymedzenom čase a množstve a v rôznych fázach podl’a správania sa zákazníka.

Tieto všetky možnosti ponúka internetová reklama. Základným faktorom úspechu však aj nad’alej zostáva dokonalé poznanie príjemcu reklamy, jeho postojov, prianí a preferencií. Na druhej strane by všetky marketingové aktivity boli zbytočné bez poznania ochoty jednotlivých segmentov použivatel'ov akceptovat' rôzne druhy reklamy. Ciel'om tohto článku je stanovenie miery akceptácie viacerých druhov internetovej reklamy a hlavne určenie hraničnej miery tejto akceptácie.

\footnotetext{
* Ing. Vladimíra Žiačková., Žilinská univerzita v Žiline, Fakulta prevádzky a ekonomiky dopravy a spojov, katedra spojov, Univerzitná 1, 01026 Žilina,

e-mail: vladimira.ziackova@fpedas.uniza.sk

* doc. Ing. Radovan Madleňák, PhD., Žilinská univerzita v Žiline, Fakulta prevádzky a ekonomiky dopravy a spojov, katedra spojov, Univerzitná 1, 01026 Žilina,

e-mail: radovan.madlenak@fpedas.uniza.sk
} 


\section{Metodika}

V prostredí internetu je možné aplikovat' všetky metódy marketingového prieskumu. Stanovením metód prieskumu sa napíňajú ciele prieskumu. V podstate sa pri výbere metódy prieskumu uplatňujú tri prístupy, a to predbežný, popisný a kauzálny prieskum. Realizovaný popisný prieskum odpovedá na sústavu hypotéz, pričom vstupné údaje sú získavané väčšinou dotazníkovými akciami.

V prípade prieskumu realizovaného $\mathrm{v}$ rámci tejto úlohy je použitá metóda elektronického dopytovania, tzv. CAWI (Computer Assisted Web Interviewing) prostredníctvom emailu oboma uvedenými spôsobmi. Výhodou elektronického dopytovania je minimálna finančná a časová náročnost'. Rozosielanie emailov je mnohonásobne rýchlejšie ako rozosielanie klasickej pošty. Spracovanie odpovedí je omnoho jednoduchšie, pretože všetky údaje, teda aj odpovede sú v elektronickej podobe. Za d'alšiu výhodu je možné považovat' adresnost', ked’že konkrétne webové stránky, prípadne diskusné fóra navštevujú používatelia, ktorých problematika práve týchto stránok zaujíma. [2]

Dopytovanie je najrozšírenejšou metódou zberu údajov, ktorý je súčast'ou realizačnej fázy procesu marketingového prieskumu. Dotazník je vd’aka svojej flexibilite najbežnejším nástrojom, ktorý sa pri zbieraní údajov používa. V dotazníku, ktorý bol rozosielaný emailom sú použité uzatvorené, otvorené aj kombinované otázky. Rozdelený je do 4 častí:

- demografické otázky,

- všeobecné znalosti práce s internetom,

- používatel'ské preferencie v oblasti internetovej reklamy,

- akceptovanie jednotlivých foriem internetovej reklamy.

Pre tvorbu dotazníka bola využitá aplikácia SelectSurvey.Net, ktorá umožní odpovede od respondentov nielen zozbierat', ale priamo aj vyhodnotit'. Súborom respondentov je jednoduchá náhodná vzorka, to znamená, že každý člen populácie má šancu byt' vybraný.

\section{Charakteristika marketingového proeskumu}

- Ciel'prieskumu:

Určenie miery akceptácie internetovej reklamy ako aj jej jednotlivých druhov pre určitý zákaznícky segment.

- Typ prieskumu:

Zvolený bol kvantitatívny prieskum.

- Čas realizácie prieskumu

3. marec 2009 - 2.42009

- Ciel'ová skupina:

Ciel'ovou skupinou sú fyzické osoby vo všetkých vekových kategóriách.

- Vybraná metóda:

Pre zber údajov bola využitá metóda elektronického dopytovania. Hlavným prvkom použitej metódy sú aplikácie postupu reprezentatívneho dotazníkového prieskumu v prostredí internetu.

- Vel'kost' vzorky respondentov: 208.

Po dokončení marketingového prieskumu bola následne realizovaná segmentácia používatel'ov internetového trhu [3]. 


\section{Segmentácia}

Každý trh, aj internetový je tvorený vel'kým počtom zákazníkov, ktorí sa od seba líšia svojimi potrebami, možnost'ami a inými charakteristikami. Každá charakteristika môže byt' využitá k rozčleneniu celkového trhu na menšie trhy, čiže na trhové segmenty, ktoré spájajú zákazníkov s určitými typickými vlastnost’ami. Segmentácia trhu je vo všeobecnosti považovaná za jeden z najdôležitejších nástrojov marketingu.

Segmentácia trhu je rozdelenie trhu prípadne zákazníkov do určitých skupín, ktoré sú vnútorne rovnorodé (homogénne) a medzi sebou rôznorodé (heterogénne) [5].

Pre riešenie stanoveného problému stanovenia medznej miery akceptácie internetovej reklamy bola zvolená segmentácia na základe psychografických premenných v kombinácii $\mathrm{s}$ prístupom ku technológiám. Z tohto pohl'adu boli používatelia internetu rozdelení do nasledujúcich segmentov [3]:

- Konzervatívni tradicionalisti;

- Kritickí racionalisti;

- Hédonici;

- Otvorení pragmatici;

- Stredný prúd;

Ako ciel'ový segment pre účely d'alšej analýzy bol vybraný segment s názvom „Stredný prúd“. Tento segment bol vybraný kvôli vzorke respondentov, ktorá zahŕňa používatel'ov s rovnomerne rozdelenými charakteristikami. Ide o segment, ktorý zahŕňa $86 \%$ respondentov vo vekovom intervale 20 - 29 rokov, $10 \%$ v intervale $30-39$ rokov a $5 \%$ v intervale 40 - 49 rokov. Osoby v tomto segmente sa vyznačujú používaním internetu na nadštandardnej úrovni. Je to najvyrovnanejší segment z hl'adiska ekonomickej aktivity rovnaké 33 percentné zastúpenie majú osoby v pracovnom pomere, podnikatelia aj študenti. Tvorí ho 48 \% mužov a 52 \% žien [3].

\section{Stanovenie medznej miery akceptácie internetovej reklamy pre zvolený segment}

$\mathrm{Na}$ začiatku sa zhodnotí vnímanie reklamy na internete všeobecne bez ohl'adu na jej druh. Respondenti mali možnost' vyznačit' v dotazníku viac odpovedí, preto je percentuálne vyhodnotenie nasledujúce:

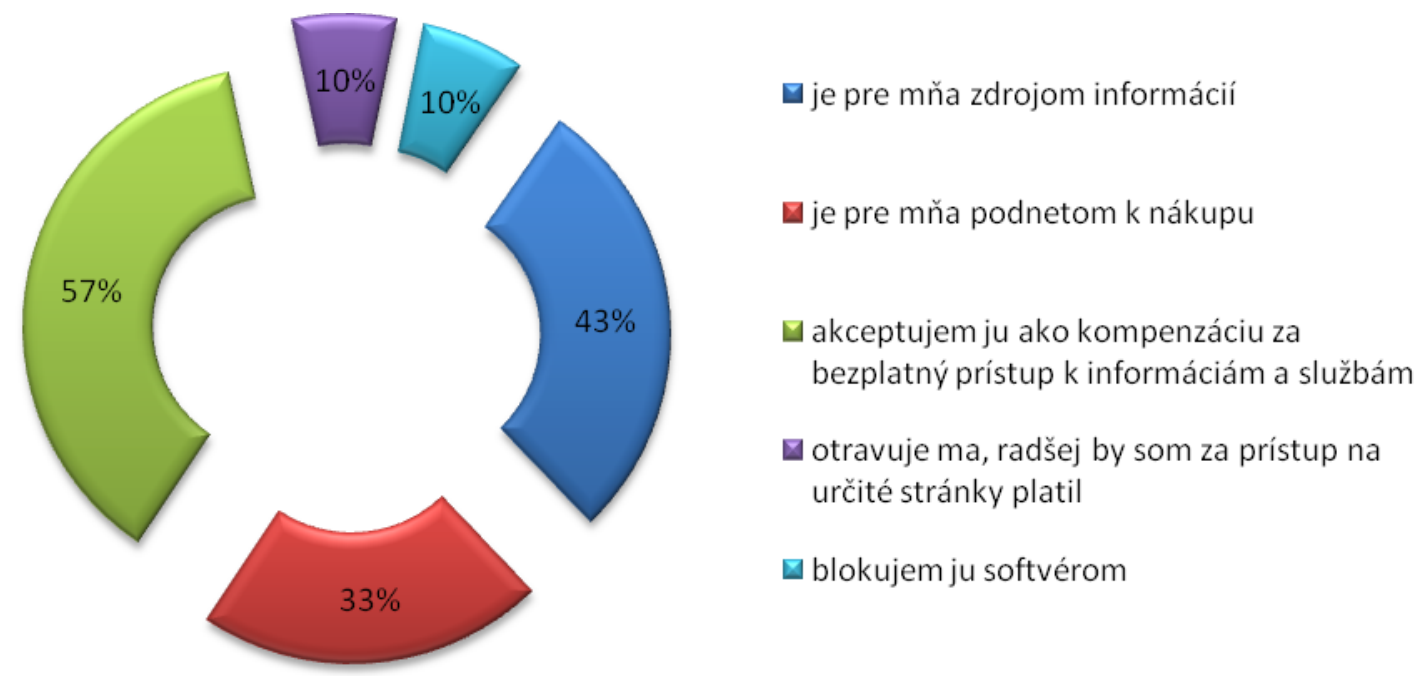

Obrázok 1. Postoj používatel’ov k internetovej reklame [3] 
Z obrázku 1 vidiet', že 57 \% opýtaných akceptuje internetovú reklamu ako kompenzáciu za bezplatný prístup k informáciám a službám a pre 43 \% je zdrojom užitočných informácií. $33 \%$ respondentov podnecuje internetová reklama k nákupu. Určitá čast' respondentov sa vyznačuje aj negatívnym postojom $\mathrm{k}$ online reklame i napriek tomu, že hodnotenie sa nevzt'ahuje na konkrétne typy reklamy. $10 \%$ z nich reklamné prvky obt’ažujú natol'ko, že sú ochotní radšej za prístup na určité stránky platit' a 10 \% využíva softvér pre blokovanie reklamy.

\section{Hodnotenie reklamy v rámci druhov}

Takmer polovica internetových používatel'ov, ktorí sa zúčastnili prieskumu zdiel'a názor, že rozsah reklamy na slovenských portáloch zatial' nie je prekážkou a $22 \%$ opýtaných považuje rozsah za primeraný. Naopak, až 31 \% si myslí, že v súčasnosti reklama na slovenských internetových stránkach prekračuje hranice únosnosti a nastalo úplne nasýtenie portálov reklamnými prvkami.

Vel'mi dôležitým prvkom je určenie hranice, ktorá predstavuje zlomový bod medzi akceptáciou online reklamy a jej úplným ignorovaním. Na základe identifikácie tejto medznej miery akceptácie je možné následne rozdelit’ recipientov reklamy do dvoch skupín, ktoré sa vyznačujú:

口 úplným odmietaním akejkol'vek formy online reklamy,

口 pozitívnym vnímaním internetovej reklamy a ochotou akceptovat' ju.

V rámci prieskumu bola pozornost' zameraná na vybrané formy reklamy, ked’že nie je možné pokryt' všetky formy online reklamy, ktorá sa v súčasnosti objavuje na serveroch (vo vel'kej miere je to napr. kontextová, intextová reklama, internetové PR, PPC reklama a pod.). Preto boli pre účely prieskumu zvolené tieto druhy [4]:

- display advertising,

- informačné stránky firiem,

- emailová reklama,

- platené odkazy a

- reklama v diskusných skupinách.

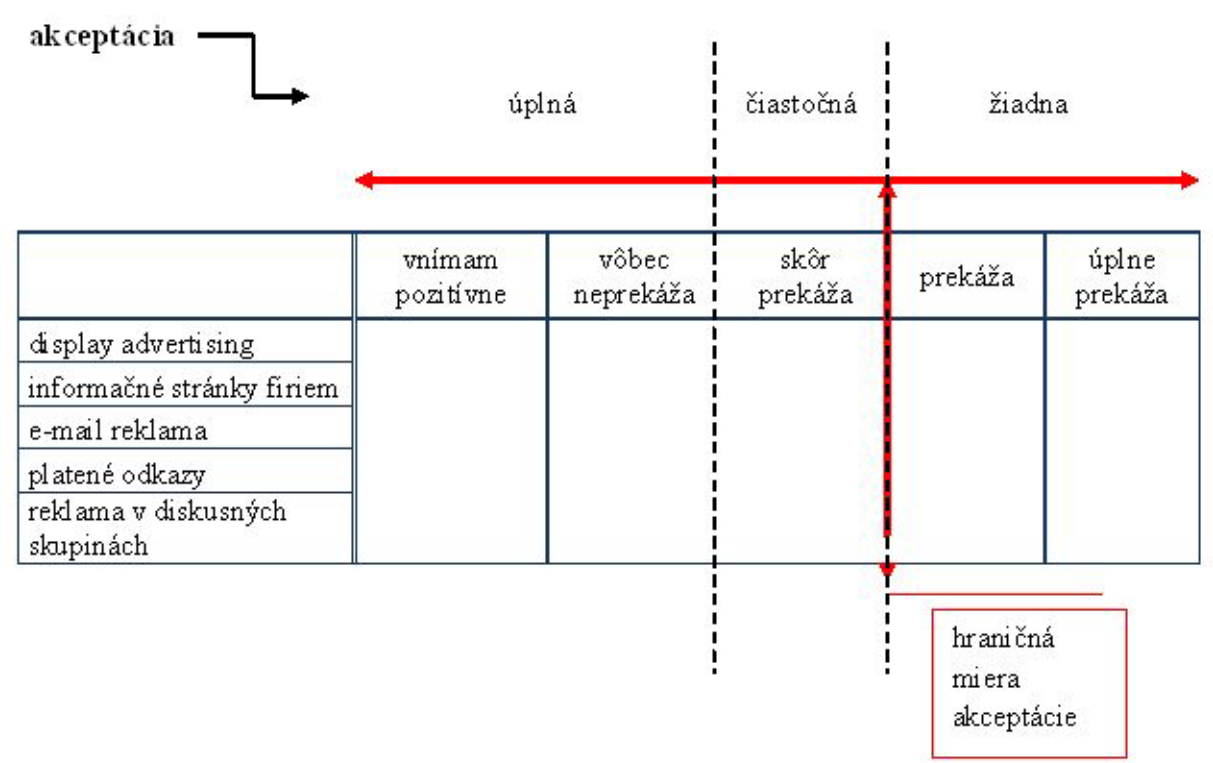

Obrázok 2. Určenie medznej miery akceptácie [3] 
Medzná miera akceptácie používatel'mi bola stanovená ako hranica medzi čiastočnou a žiadnou akceptáciou ako znázorňuje obrázok 2. Je predpoklad, že používatelia, ktorým reklama skôr prekáža sú predsa len ochotní, aj ked' v malej miere určitý typ reklamy prijat', preto bola hraničná miera určená až za touto možnost'ou výberu [6].

Hraničná miera bola identifikovaná pre každý typ reklamy zvlášt' ako konkrétna číselná hodnota. Táto hodnota predstavuje súčet percentuálnych podielov zvolených možností siahajúci po vopred definovanú hranicu, čiže vypovedá o tom, kol'ko percent opýtaných je v stanovenej miere ochotných reklamu akceptovat'. Ak sa prekročí táto hodnota, daný reklamný prvok bude považovaný za neakceptovatel'ný pre daný používatel'ský segment.

Vyhodnotenie prieskumu pre jednotlivé druhy reklamy sú znázornené v nasledujúcom prehl'ade (obrázok 3).

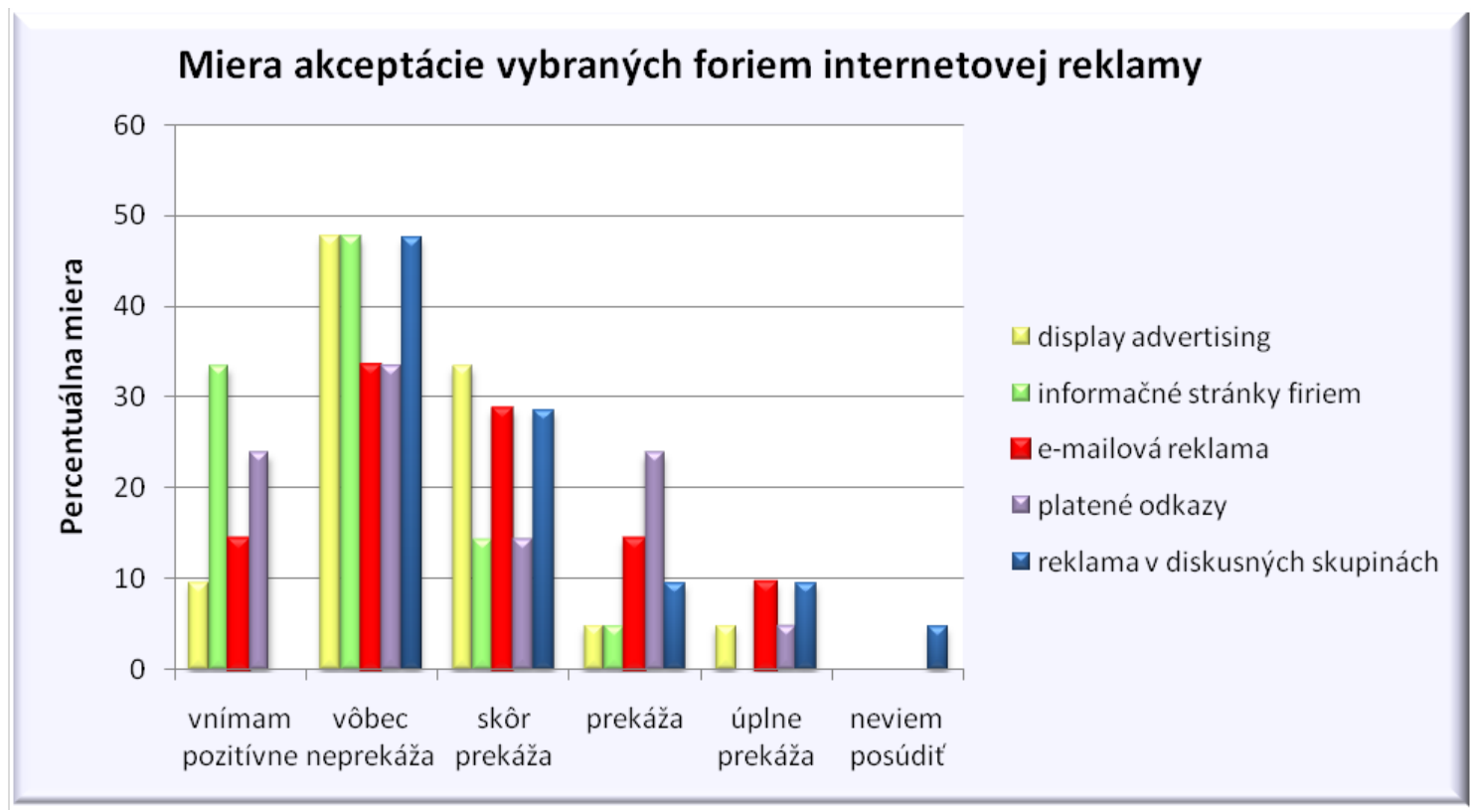

Obrázok 3. Miera akceptácie vybraných foriem online reklamy [3]

Najlepšie výsledky v hodnotení prijatel’nosti dosahujú informačné stránky firiem a následne display advertising. Týmto sa potvrdili všeobecne známe poznatky o prijatel'nosti týchto foriem a naproti tomu poznatky o menšej ochote používatel'ov akceptovat' emailovú reklamu a reklamu v diskusných skupinách. Najmenej akceptovatel'nou formou reklamy pre zvolený segment sú platené odkazy, čo je dost' prekvapujúci výsledok.

Po stanovenú hraničnú mieru (vid' obrázok 2) sú konkrétne hodnoty miery akceptácie nasledujúce:

display advertising - 90,47 \%,

informačné stránky firiem - 95,24 \%,

emailová reklama - 76,19 \%,

- platené odkazy - 71,43 \%,

- reklama v diskusných skupinách a konferenciách - 76,19 \%.

Z týchto hodnôt je zrejmé, že najväčší podiel - 95,24 \% opýtaných si vybralo možnost' úplnej alebo čiastočnej akceptácie informačných stránok firiem. V rámci reklamy zobrazovanej na obrazovke môžeme konštatovat', že 90,47 \% respondentov pokladá túto formu reklamy za akceptovatel'nú a len 9,53 \% ju považuje za neprijatel'nú. Emailovú reklamu je ochotných akceptovat' 76,19 \% respondentov, čo je dost' vysoká hodnota vzhl'adom na fakt, že v rámci doteraz realizovaných prieskumov bola distribúcia reklamy prostredníctvom emailovej pošty úplne neprijatel’ná. 
Najmenšie percento respondentov $(71,43 \%)$ považuje za prijatel'né platené odkazy. Všetky tieto čísla však hovoria o vel'mi dobrej prijatel'nosti všetkých foriem online reklamy práve vybraným segmentom používatel'ov internetu [3].

\section{Záver}

Internet a reklama. Toto spojenie predstavuje vel'mi silný nástroj pre oslovenie širokého spektra používatel'ov internetu rôznych vekových kategórii, rôzneho vzdelania, z rôznych sociálnych skupín a z rôznych geografických oblastí. Všetky tieto charakteristiky sú dôležité pri určovaní skupiny l'udí, čiže konkrétneho segmentu, na ktorý je účelné zamerat' sa v rámci reklamnej kampane. Tento článok priniesol pohl'ad na to ako vybraný segment všeobecne akceptuje základné druhy internetovej reklamy. Ďalšie, detailnejšie informácie o tom aká je medzná miera akceptácie jednotlivých typov internetovej reklamy budú publikované v budúcom čísle tohto časopisu.

\section{Literatúra}

[1] DOUBRAVOVÁ, J.: Jak účinně propagovat služby v ČR a zahraničí?. In: Marketing magazine. Praha: Mladá fronta, a. s., 2009, č. 3, s. 28.

[2] KOZEL, R.: Moderní marketingový výzkum. Grada Publishing, a. s., Praha, 2006. ISBN 80-247-0966-X.

[3] ŽIAČKOVÁ, V.: Identifikácia medznej miery akceptácie foriem internetovej reklamy pre vybraný zákaznícky segment, Diplomová práca, 117/2009 KS, Katedra spojov, ŽU Žilina, 2009

[4] MADLEŇÁK, R..: Elektronický obchod. Vydavatel'stvo EDIS, Žilina, 2004. ISBN 808070-192-X.

[5] ROSTÁŠOVÁ, M.: Marketing v službách. Vydavatel'stvo EDIS, Žilina, 2005. ISBN 808070-355-8.

[6] MADLEŇÁKOVÁ, L.: K problematike hodnotenia spokojnosti zákazníka, In: POSTPOINT 2005 : medzinárodná konferencia zástupcov poštových správ a univerzít, Katedra spojov, ŽU Žilina, Žilina 28. - 30. september 2005, ISBN 80-8070-454-6.

\section{Grantová podpora}

- VEGA 1/0468/08 - Inovačné stratégie v sektore služieb

- VEGA 1/4573/07 Možnosti, ohraničenia a vývojové tendencie koncepcie univerzálnej služby v pošte a telekomunikáciách v procese globalizácie

- VEGA 1/0149/10 Difúzne procesy nových mobilných služieb a ich hodnotový ret’azec 